\title{
砂および粘土の繰返しせん断強度に基づく 有効応カモデルとその液状化解析への適用
}

\author{
山本陽 ${ }^{1} \cdot$ 兵動正幸 ${ }^{2} \cdot$ 黒島一郎 $^{3} \cdot$ 谷垣正治 $^{4}$ \\ ${ }^{1}$ 正会員 工修 三井建設（株）技術研究所（广 270-01 千葉県流山市駒木518-1） \\ ${ }^{2}$ 正会員 工博 山口大学助教授 工学部社会建設工学科 ( 755 山口県宇部市常盤台2557) \\ プェロー会員 三井建設（株）土木技術部（广261 千葉県千葉市美浜区中瀬1-9-1） \\ ${ }^{4}$ 工博 三井建設 (株) 技術研究所 (厂270-01 千葉県流山市駒木518-1)
}

\begin{abstract}
本論文では，地震時の飽和砂および粘性土の破壊過程を表現可能な実用性の高い有効応力モデルを実験 的な検討を踏まえて提案する. 提案するモデルは新たな応力経路モデルと有効応力比・ひずみ関係に基づ くモデルから構成されており，応力経路モデルについては強度曲線を直接用いたモデル化を行っている. さらに，兵庫県南部地震 (1995) の際に激しい液状化現象が見られたポートアイランドでの鉿直アレー観測 記録のシミュレーションに基づいて，提案モデルの妥当性と強震時の地盤応答について検討を行った.
\end{abstract}

Key Words : cyclic mobility, cyclic strength line, earthquake, effective stress model, ground response, liquefaction, soil nonlinearity

\section{1. まえがき}

1995 年 1 月 17 日に発生した兵庫県南部地震では, 臨海部の埋め立て地盤を中心として大規模な液状化 が生じた。これを契機に大規模地震動に対する地盤 の評価法として, 有効応力法による地震応答解析の 有用性が再認識されている. 大きな地震動に対して は, 緩い砂質地盤のみならず, 密な砂質地盤や粘性 土地盤についても破壊に至る可能性が考えられるが， この場合, 砂質土についてはサイクリックモビリテ イの評価が重要であると思われる. 兵庫県南部地震 の際に激しい液状化現象が見られたポートアイラン ドの鉛直アレー観測記録については, 地震後既にい くつかの有効応力解析プログラムによるシミュレー ション ${ }^{11}$ ．2).3)が行われているが，いずれも顕著な サイクリックモビリティ現象が生じていたことが明 らかにされている。 また, 森ら ${ }^{4)}$ は Superstition Hill 地震 (1989) において, 井合ら ${ }^{5)}$ は釧路沖地震 (1993) において完全に液状化した地点の観測波形中に, サ イクリックモビリティの影響が現れていることを示 している. このように, 程度の差こそあれ大抵の砂 質地盤の液状化現象には, サイクリックモビリティ 挙動を伴う場合が多いように思われる. 一方，粘性 土地盤については先の地震による被害も未だ明らか ではないが, 吉田 ${ }^{1)}$ は解析結果から沖積粘土層の非 線形性が地盤の応答に大きく影響したことを指摘し
ている.

さて, 有効応力解析法に関する研究は現在も活発 になされており, 土の構成モデルは高度に発展して いる. 一方で詳細な解析が可能となるにつれて, 解 析に必要なパラメータの設定や解析結果の精度等の 解釈に関して高度な工学的判断を必要とすることが 多くなってきている. しかも, 一般に土の繰返しせ 儿断試験から得られる液状化強度曲線や変形特性曲 線等を直接的に用いることが不可能なことも問題と 考えられる.また，構成モデルが高度になっている にも関わらず，サイクリックモビリティについては その評価方法が未だ不明瞭で不完全であるように思 われる．また，それらのモデルは砂質土に対するも ので, 粘性土についてはほとんど考慮されていない のが実状である.この結果, 実務検討においては地 盤の非線形性を本来最も厳密な形で評価し得るはず の有効応力解析は, 全応力解析法である等価線形解 析ほど一般的な用途として供されていない. したが って, 有効応力法による地震応答解析が広く実用に 供されるためには, 解析パラメータの設定が容易で かつその方法や根拠が明確であること，さらに大規 模地震動を想定した検討では, 土の破壊過程の挙動 を適切に評価可能である必要があると考えられる.

本研究はこの点を踏まえ, 有効応力法の特長を生 かしながら，手法の一般化と簡易化を目指した実用 性の高いモデルの提案を行うものである，提案する 


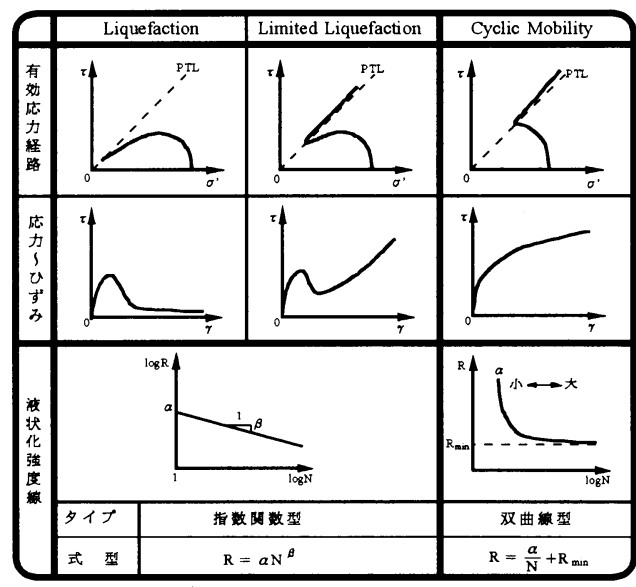

図-1 サイクリックモビリティーの定義

モデルは新たな応力経路モデルと有効応力比・ひず み関係に基づくモデルから構成されている．応力経 路モデルについては, 繰返し試験結果の表現方法と して最も一般的で，実験データの蓄積も豊富な繰返 し強度曲線の中に繰返しせん断挙動に関する多くの 情報が含まれていることに着目して，これを直接用 いたモデル化を行っている．モデルは，砂質土の液 状化を前提として構筑されているが，粘性土の破壊 過程についても一貫した評価が可能な形になってい る. さらに, 提案モデルの地震応答解析法への適用 性の検証と強震動時の地盤の応答性状を明らかにす る目的で，前述のポートアイランドで得られた鉛直 アレー観測記録のシミュレーションを行った.

尚，実施した試験は非排水静的および繰返し三軸 試験でその結果は，せん断応力 $\tau=\left(\sigma_{a}-\sigma_{\mathrm{r}}\right) / 2$, せん断ひずみ $\gamma=(1+v) \varepsilon_{a}$, 平均有効主応力 $\sigma^{\prime}=\left(\sigma^{\prime}{ }_{a}+2 \sigma^{\prime}{ }_{r}\right) / 3$, 有効応力比 $\eta=\tau / \sigma^{\prime}$ として整理を行っている（ $\sigma_{a}$ : 軸方向応力, $\sigma_{r}$ : 側方応力, $\varepsilon_{a}$ : 軸ひずみ, $v$ : ポアソン比 $(=$ 0.5) . また, 解析は一次元のせん断変形を仮定し $\tau \tau=\tau_{x y}, \gamma=\gamma_{x y}$ としている.

\section{2. サイクリックモビリティの定義と液状化 強度曲線の定式化}

Castro $ら^{6)}$ や Vaid $ら^{7)}$ は，一般に液状化と呼ば れる現象について, 非排水単調せん断挙動に対応さ せる形で次のような区別を行っている（図-1参照）。

Liquefaction：収縮一方でついには定常状態に至 るもの.

Limited Liquefaction : 収縮挙動の過程においてひ ずみ軟化を示した後に，膨張傾向に転じて強度の回

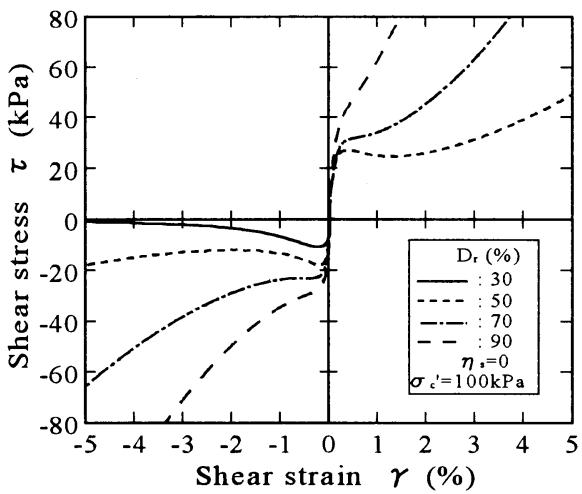

(a ）せん断応力・せん断ひずみ関係

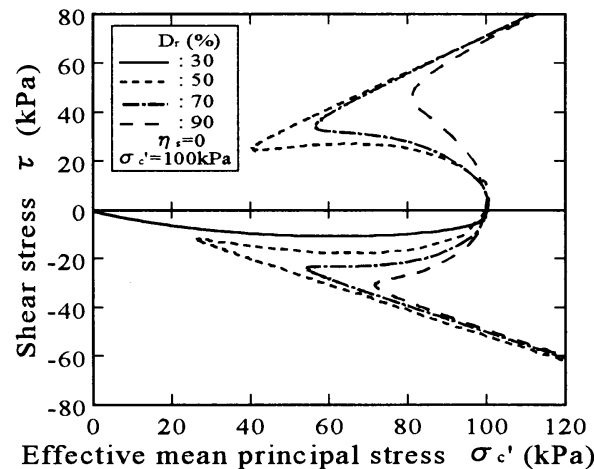

(b) 有効応力経路

図-2 豊浦砂の非排水三軸試験結果

復をするもの.

Cyclic Mobility : ひずみ軟化を生じず，膨張傾向 にあるもの.

図-2に，種々の相対密度の豊浦砂に対して実施し た非排水静的三軸試験結果を示したが，この定義に 従えば， $D_{r}=70 ， 90 \%$ の結果がサイクリックモビ リティに $D_{r}=50 \%$ の結果が Limited Liquefaction, そ して $D_{r}=30 \%$ の伸張せん断挙動が Liquefaction にそ れぞれ相当している．図-3はこれらの繰返し三軸試 験結果として $D A=5 \%$ で規定した液状化強度曲線 を相対密度に対して比較したものである．強度線は， 密度が高くなるほど繰返し回数の少ないところにお いて立ち上がる傾向にあり，特に $D_{r}=70 ， 90 \%$ の 強度線においてこの傾向が顕著である．図-4, 図-5 は，それぞれ豊浦砂 $D_{r}=30 ， 90 \%$ の液状化強度曲 線を，所定の軸ひずみ両振幅 $D A=1 ， 2 ， 5$, $10 \%$ に対して示したものである. $D_{r}=30 \%$ の強度 曲線は，液状化に至ると同時に一気に変形が進行す るために，ひずみ振幅の規定による違いは認められ ない。一方， $D_{r}=90 \%$ の場合は，ひずみの規定に よる強度線の違いが明確で, 強度の立ち上がり傾向 


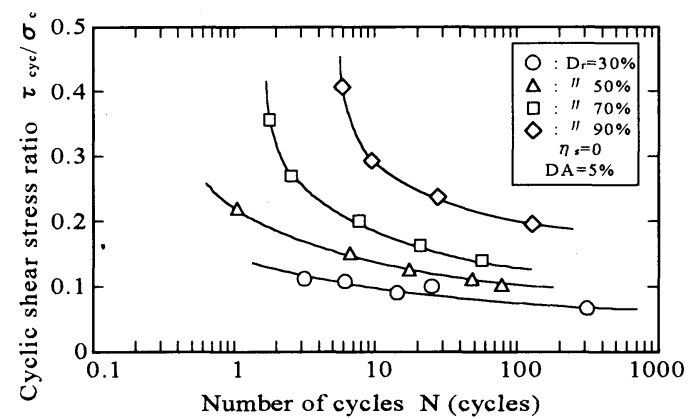

図-3 相対密度による液状化強度曲線の比較

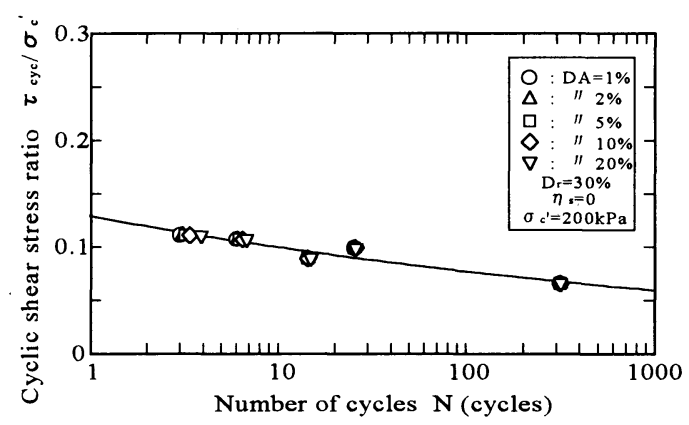

図-4 所定の軸ひずみ両振幅に至るに必要な 繰返しせん断応力比・繰返し回数関係 (豊浦砂 $D_{r}=30 \%$ )

が，ひずみの発達とともに大きくなることを表して いる.

このように, 強度曲線に見られる急激な立ち上が りは, 変相後の膨張性挙動に起因したサイクリック モビリティによる強度增加を強く反映している。 ま た, 強度曲線の立ち上がりの程度は, 先のサイクリ ックモビリティの反映も含めて, 液状化中の砂の変 形挙動を表していると考えられるので，これを直接 利用することによって，解析パラメータの設定や解 析結果の精度等の解釈に関してより容易なモデル化 が可能になると考えられる.

この場合，強度曲線を何らかの方法で定式化する ことが必要となるが，立ち上がりの傾向を示す強度 曲線に対しては，次式に示す双曲線による近似が有 効であることが知られている8 ${ }^{8}$.

$$
R_{f}\left(\tau_{c y c} / \sigma^{\prime}\right)_{f}=\alpha / N+R_{\text {min }}
$$

ここで， $R_{\min }$ は $N=\infty$ における液状化強度であり， ひずみ振幅の大きさによらない， $\alpha$ は強度曲線の 立ち上がりの程度を規定するパラメータである。 図-5中に描いた曲線は上式により回帰したものであ る.ここで， $\alpha$ を片振幅軸ひずみ $\varepsilon_{S A}(=D A / 2)$ に対してプロットしたのが図-6である．図から明ら かなようにプロットしたひずみの範囲では両者が比

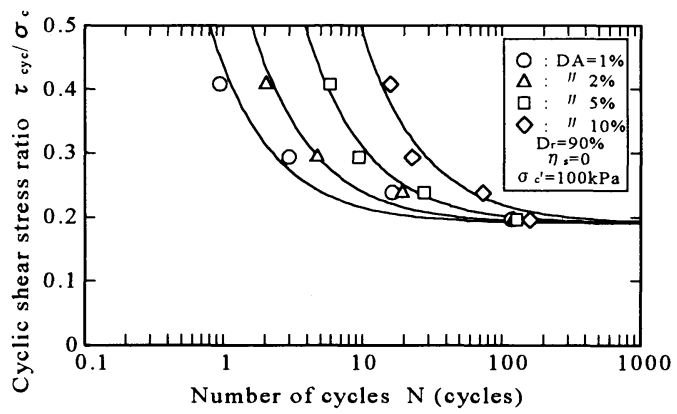

図-5 所定の軸ひずみ両振幅に至るに必要な 繰返しせん断応力比・繰返し回数関倸 (豊浦砂 $D_{r}=90 \%$ )

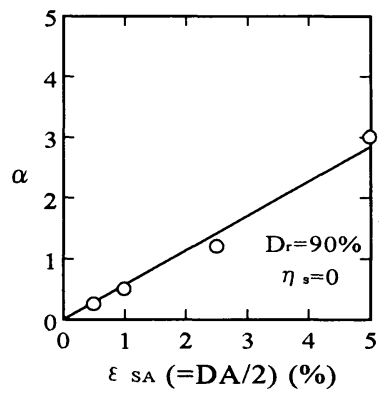

图-6 定数 $\alpha$ と片振幅軸ひずみの関倸 (豊浦砂 $D_{r}=90 \%$ )

例関係にあることが分かる．したがって， $\alpha$ に関 して次式を与えることができる.

$$
\alpha=C_{1}+C_{2} \varepsilon_{\text {sA }}
$$

ここで, $C_{1}, C_{2}$ は回帰に伴う定数である.

\section{3. 有効応カ比〜ひずみモデル}

サイクリックモビリティに関する見逃せない現象 として応力〜ひずみ曲線の形状がある。図-7（a），

（b），（c）には，豊浦砂 $D_{r}=90 \%$ の繰返し三 軸試験から得られた，せん断応力 $\tau$ 〜ん断ひず み $\gamma$ 関係, 有効応力比 $\eta$ 〜せん断ひずみ $\gamma$ 関係, 有効応力経路をそれぞれ示した．通常，有効応力経 路が変相線に至るまでの応力〜ひずみ履歴曲線は紡 錘型の形状をしているが，変相以降においては，有 効応力経路の位相の逆転により, 逆 S 字の形状を 示す. これは，有効応力の回復に伴い剛性が増加す るために，この過程のひずみ増加が抑えられるため に他ならない. 一方の, $\eta \sim \gamma$ 関係は変相後のサ イクリックモビリティにおいても紡錘型の履歴曲線 の形状を保っている，また，図一8は繰返しせん断応 力ピーク時の有効応力比 $\eta_{p}$ と片振幅せん断ひずみ $\gamma_{s a}$ の関係を異なる繰返しせん断応力条件での試験 


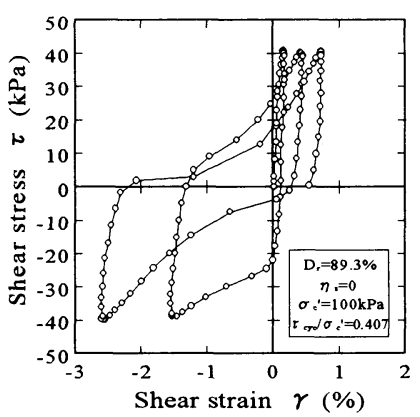

（a ）せん断応力・せん断ひずみ関係

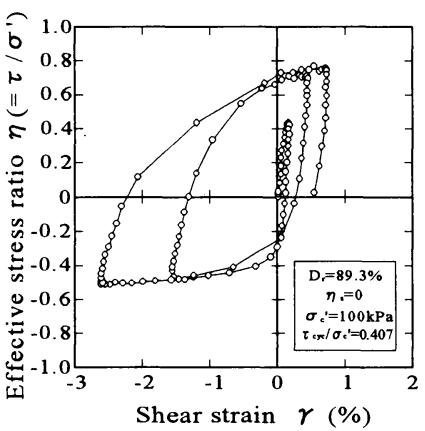

（b）有効応力比・せん断ひずみ関係

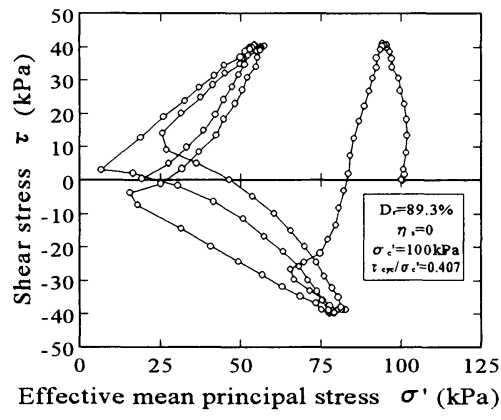

（c）有効応力経路

図-7 豊浦砂 $D_{r}=90 \%$ の非排水繰返し三軸試験結果

結果を含めてプロットしたものであるが，両者の関 係は, 繰返しせん断応力比 $\tau_{c c c} / \sigma{ }^{\prime}$ 。 繰返し回数 の違いによらず一義的である．さらに，図-9は，サ イクリックモビリティ時の $\eta \sim \gamma$ 履歴曲線につい て，異なる 2 種類の繰返しせん断応力条件での試験 結果を示したものであるが，履歴曲線についても折 り返し時の有効応力比が等しければ，繰返しせん断 応力比や繰返し回数の違いによらず一義的に表され ることが分かる.

このような特徴を有する有効応力比〜ひずみ関係 に対して, 柴田ら ${ }^{9)}$ や兵動ら ${ }^{10)}$ は骨格曲線につい て, 原ら ${ }^{11)}$ や三原ら ${ }^{12)}$ は履歷曲線についても双曲 線による近似が有効であることを示している．本モ デルにおいてもこれと同様な方法により，有効応力 比〜ひずみ関係を表現することとした。

まず，図-8の関係は処女載荷時の骨格曲線に相当 するものであり，これを次式で与えた。

$$
\gamma=\frac{\eta}{\frac{G_{\max }}{\sigma^{{ }^{\prime}}}\left(1-\frac{\eta}{\eta_{f}}\right)}
$$

ここで， $G_{\max }$ は微小ひずみ時のせん断剛性であり， $\eta_{f}$ は破壊時の有効応力比である. 図-8中の実線は, 試験結果の $G_{\max }$ と $\eta_{f}$ から, 上式により求めたもの である.

次に履歴曲線は, 繰返し載荷中の $\eta \sim \gamma$ 関係が Masing 則に従うものとして, 式 (3) を拡張した次式 で与えた。

$$
\gamma=\gamma_{\circ}+\frac{\eta-\eta_{o}}{\frac{G_{\max }}{\sigma^{\prime}{ }_{c}}\left(1-\frac{\eta-\eta_{\circ}}{2 \eta_{f}}\right)}
$$

ここで， $\left(\gamma_{o}, \eta_{0}\right)$ は折り返し点の值である. 式

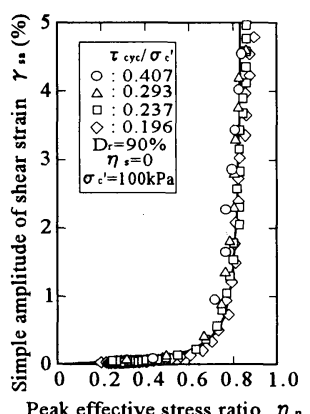

图-8 ピーク有胶店力比. 片振幅ひずみ関係

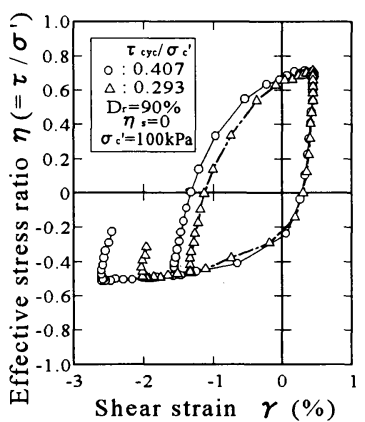

図-9 有効応力比・ひずみ 履歴曲線の比較

(3)，(4) で与えられる有効応力比〜ひずみモデル は, $\sigma^{\prime}=\sigma^{\prime}$, , つまり, 有効応力が初期有効応力 に等しく, 変化しないとする時, 非線形全応力モデ ルであるHardin-Drnevichi モデル ${ }^{13)}$. 14) に一致する.

このように，有効忘力比〜ひずみ関係に基づいた モデル化を行うことにより，初期状態から破壊過程 であるサイクリックモビリティについて，終始一貫 した変形の評価が可能となる. さらに, 有効応力比 〜せん断ひずみ関係は，せん断応力，有効応力，ひ ずみの三者を関連づけるものなので，有効応力を通 して, 後で示す応力経路モデルと一体化した剛性の 評価が可能となる.

\section{4.応力経路モデル}

応力経路モデルは，室内試験結果に基づいた降伏 条件を設けて有効応力経路を定め，これにより繰返 し載荷過程の各段階で間隙水圧の発生量を予測する ものであり，代表的なモデルとして Ishihara $5^{15)}$ のモデルがある

ここで提案するモデルは，先に行った強度曲線の 定式化に基づいて構築しているが，繰返しせん断時 


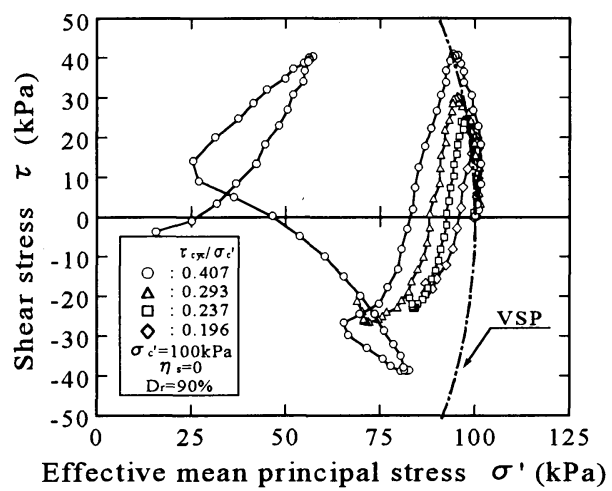

図-10 処女有効応力経路VSP

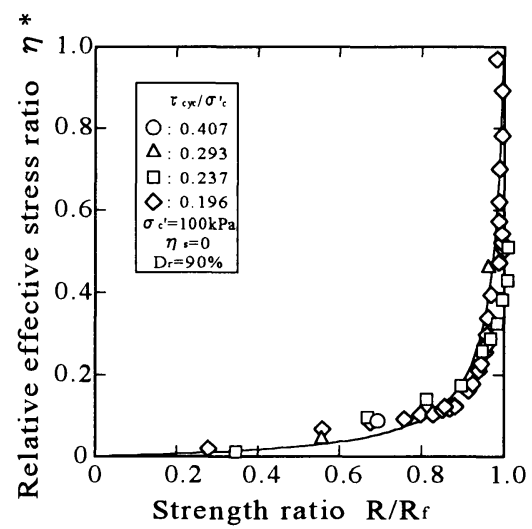

図-11 相対有効応力比・強度比関係
の有効応力経路から明らかなように, 変相線 PTL

(Phase Transformation Line) に至る過程とそれ以 降のサイクリックモビリティ挙動とでは全く異なっ たものとなっているので, 変相線を境に分けて評価 を行っている.

\section{（1）変相状態に至る過程の応力経路の定義}

まず，初期の降伏条件として次の仮定を設けた.

(1) 初期降伏条件を $|\eta| \geqq\left|\tau_{\text {min }} / \sigma^{\prime}{ }_{c}\right|$ とす る.ここで, $\mid \tau_{\min } / \sigma^{\prime}$ 。| は最小の液状化強度で あり，式(1)で与えらた $R_{\text {min }}$ に他ならない。この条 件を満たさない場合の応力経路は, 以下に定める VSP（Virgin Stress Path）で与えられる.

図一10は異なる繰返しせん断応力条件の試験結果 において, 最初の半サイクルの有効応力経路を重ね て示したものであるが，処女載荷過程においては， 繰返しせん断応力の大きさに関係なく, 同一の応力 経路上にあることが明らかである. そこで，これら の経路を包絡する曲線を次式で与え, この経路を VSP と定義する.

$$
\Delta \sigma^{\prime}=-\frac{\tau \sigma^{\prime}{ }_{c}}{2 B^{2} \sqrt{1-\left(\frac{\tau}{B}\right)^{2}}} \Delta \tau
$$

ここで， $\sigma^{\prime}$ “は初期有効応力である．また，実験結 果における VSP 上の任意の点を $\left(\sigma^{\prime}{ }_{k}, \tau_{k}\right)$ とし て与えた場合, 定数 $B$ は次式で与えることができる.

$$
\begin{gathered}
B=\frac{\sqrt{\tau_{k}^{2}}}{\sqrt{1-\frac{4}{\sigma^{\prime}{ }_{c}^{2}}\left(\sigma^{\prime}{ }_{k}-\frac{\sigma^{\prime}{ }_{c}}{2}\right)^{2}}} \\
\text { ただし, } B \geqq\left|\eta_{P T}\right| \sigma^{\prime}{ }_{c} / 2
\end{gathered}
$$

ここで， $\eta_{P T}$ は変相時の有効応力比である. また，
VSP は擬似的に変相線に至るまでの静的な応力経 路を与えるものである. したがって, 定数 $B$ は変相 時のせん断強度と見なせる. つまり, $N=0.5$ 回で 変相線に達する時の繰返し強度と等価であると考え られるので, 式 (1) から与えることも可能である.

次に, 初期の降伏条件を満たした後の降伏条件は, 次のように設定した.

(2) 有効応力比が圧縮と伸張それぞれの領域にお いて, 過去最大の有効応力比を超える時 (| $\eta$ $\left.>\left|\eta_{\max }\right|\right)$ を降伏とする.

降伏後の応力経路については, 以下に示寸算定法 により与えられる.

図-11は，繰返し三軸試験から得られた相対有効 応力比 $\eta^{*} \sim$ 繰返しせん断強度比 $R / R_{f}$ 関係 ${ }^{10)}$ を示 したものである. $\eta^{*}$ は, 任意の繰返し回数におけ る応力サイクルピーク時の有効応力比 $\eta_{p}$ が, この 点のせん断応力 $\tau$ と初期有効拘束圧 $\sigma$ 。 。比で表 される初期有効応力比 $\eta_{i}$ と変相時の有効応力比 $\eta_{P T}$ との間でどのような位置にあるかを表す相対的 な応力比であり，次式で定義される（図-12参照）.

$$
\eta^{*}=\frac{\eta_{p}-\eta_{i}}{\eta_{P T}-\eta_{i}}
$$

強度比 $R / R_{f}$ は, 外力としての繰返しせん断応力 比 $R$ を変相時の繰返し強度 $R_{f}$ で除して正規化したも のであり，いわゆる液状化抵抗率 $F_{L}$ の逆数に相当す る. 図から明らかなように, $\eta^{*} \sim R / R_{f}$ 関係は繰 返しせん断応力比の違いによらず一義的であり，こ の関係を次式で与えた。

$$
\eta^{*}=\frac{R / R_{f}}{a-(a-1) R / R_{f}}
$$

ここで， $a$ は実験定数であり, 図中の曲線は上式に より回帰したものである. 


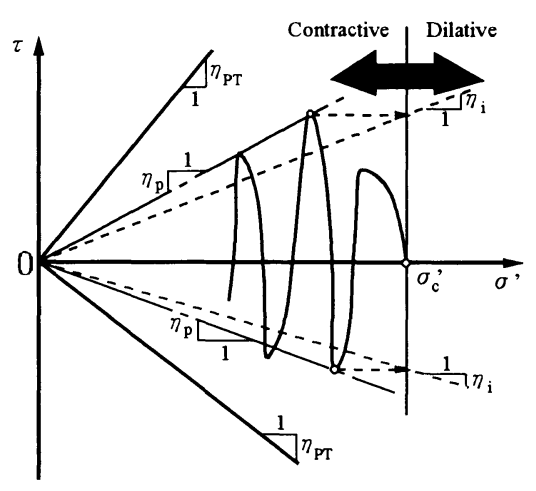

図-12 相対有効応力比の定義

これより，一定の繰返し応力振幅が作用する場合 には，有効応力 $\sigma^{\prime} \sim$ 繰返し回数 $N$ 関係を任意に算 出することができる．そこで，不規則なせん断応力 が作用する場合の有効応力の算定法として，この関

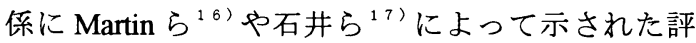
価法を適用する（図-13参照）。

今, $R\left(=\left|\tau / \sigma^{\prime}{ }_{c}\right|\right)$ なる大きさの繰返し せん断応力比が，半サイクル作用する場合を考える. この時までの繰返しせん断により，有効応力はすで に， $\sigma^{\prime}$ 。まで減少していたと仮定する，Rが，仮に 一定応力振幅として作用し，有効応力が $\sigma$ '。まで減 少するに必要な等価繰返し回数 $N_{e q}$ は, 式 (1), から次のように与えることができる.

$$
N_{e q}=\frac{\alpha_{P T}}{R \frac{1+(a-1) \eta^{*}{ }_{e q}}{a \eta^{*}{ }^{*}}-R}
$$

ここで， $\alpha_{P T}$ は先に定義した有効応力比・ひずみ関 係で $\eta=\eta_{P T}$ として与えられる変相時のひずみを 式 (2)に代入して求められる值であり, 変相時の強 度線を規定する定数である.また， $\eta^{*}{ }_{e q}$ は相対有 効応力比の定義から,

$$
\eta_{e q}^{*}=\frac{\tau / \sigma^{\prime}{ }_{o}-\tau / \sigma^{\prime}{ }_{c}}{\eta_{P T}-\tau / \sigma^{\prime}{ }_{c}}
$$

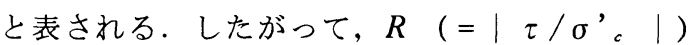
の大きさの繰返しせん断応力比が，半サイクル作用 するときの有効応力 $\sigma{ }^{\prime}$ は, $N=N_{e q}+0.5$ として評 価した $R$,を式 (8) に代入することによって，

$$
\sigma^{\prime}=\frac{\tau}{\eta^{*}\left(\eta_{P T}-\tau / \sigma^{\prime}{ }_{c}\right)+\tau / \sigma^{\prime}{ }_{c}}
$$

と与えられる.

これを引き続くせん断応力半サイクル毎に, 繰返し

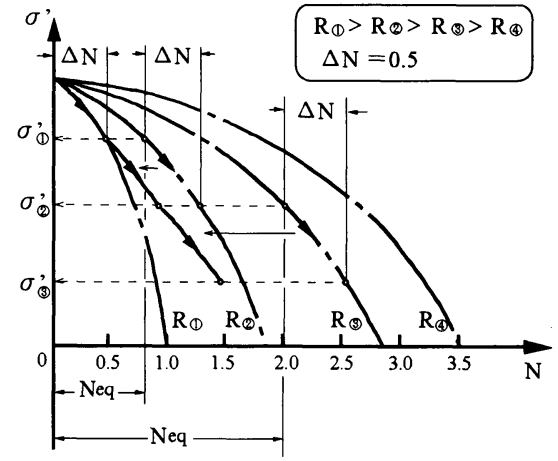

図-13 不規則載荷に対する有効応力の算定法

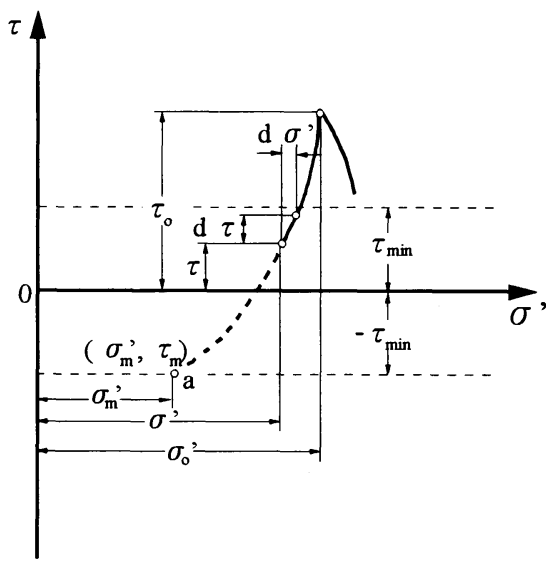

図-14 $|\tau-\tau \circ|<|\tau-\tau \min |$ の 領域における応力経路の定義

計算することによって，不規則載荷時の有効応力の 変化を評価することができる.

この有効応力算定法によりり，降伏後の応力経路を 与えることが可能となるが，降伏時のせん断応力 $\tau$ 。を基準とする応力経路上のせん断応力が $\mid \tau-$ $\tau_{o}|<| \tau_{\text {min }}-\tau \mid$ の時には, 式 (9)を用いて $N_{e q}$ を算出することができない，そこで，この領域 における応力経路は, $\tau=\tau_{\text {min }}$ として式(11) から 与えられる点 $\mathrm{a}\left(\sigma^{\prime}{ }_{m}, \tau_{m}\right)$ と降伏点 $\left(\sigma^{\prime}{ }^{\prime}\right.$, て。）とを包絡する曲線で与えることとした（図-14 参照）。つまり,

（3) 降伏後の除荷・再載荷過程において，| $\tau$ $-\tau_{0}|<| \tau_{\min }-\tau \mid$ の領域における応力経路は 次式で与えられる.

$$
\Delta \sigma^{\prime}=\frac{\Delta \tau\left(\sigma^{\prime}{ }_{o}-\sigma^{\prime}{ }_{m}\right)}{2\left(\tau-\tau_{m}\right)}
$$

ここで，降伏点のせん断応力 $\tau_{0}$ と $\tau_{\text {min }}$ との間には, $\tau_{o} \times \tau_{\min }<0$ の関係がある. 


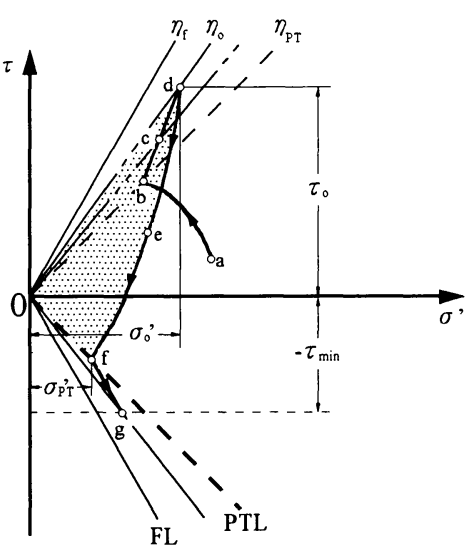

図-15 サイクリックモビリティ時の応力経路

次に, $\tau$ が $\tau_{\min }$ を越えてさらに増加していく過 程の応力経路は, 以後, どの位置で折り返したとし ても，直前の降伏点（ $\left.\sigma^{\prime}{ }_{0}, \tau_{0}\right)$ を基準に考えれ ば，半サイクルのせん断応力が作用したと考えるこ とができる.したがって,

(4) 降伏後の除荷・再載荷過程において, | $-\tau_{0}|\geqq| \tau_{\min }-\tau \mid$ の領域における応力経路は, 各時間ステップ毎に $N=N_{e q}+0.5$ として式 (9)〜式 (11)の計算を繰り返し行うことによって与えられる.

次に，折り返し点において，(2)の降伏条件を満足 しない場合の応力経路は，以下のように考えた.

(5) 折り返し点において降伏条件を満たさない場 合には, その後の有効応力の変化はなく, 応力経路 は $\Delta \sigma^{\prime}=0$ とする．ただし，載荷過程であれば直 前の降伏時の載荷過程, 除荷過程であれば直前の降 伏時の除荷過程における応力経路と等しくなり，こ れを越えるような場合は，以後これと同一の経路で 与えられる。

\section{（2）サイクリックモビリティの評価}

図-15は，サイクリックモビリティ現象を模式的 に表したものであるが，この時の挙動は，変相線を 境に有効応力が増加する領域 $(\mathrm{b} \rightarrow \mathrm{c} \rightarrow \mathrm{d}, \mathrm{f} \rightarrow \mathrm{g})$ とせん断応力の折り返しにより有効応力が減少する 領域（ $\mathrm{d} \rightarrow \mathrm{e} \rightarrow \mathrm{f} ）$ の 2 つ場合がある. そこで, この時の応力経路を, 有効応力の増加領域と減少領 域とに分けた評価によって定義する.

\section{a ）有効応力の增加領域}

今, 応力経路が変相線に達した時, これまでのせ ん断履歴により生じた最大のひずみの大きさが $\gamma 。$ であったとする（図-16参照）。この時の等ひずみ 線は強度曲線に他ならなず，式 (1)，(2) からせん

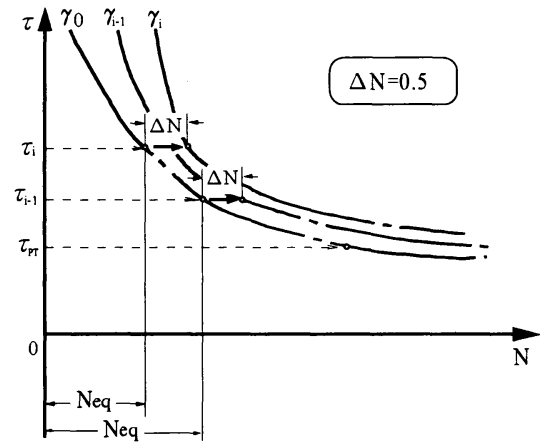

図-16 等価繰返し回数の定義

断応力比〜繰返し回数関係で表される等ひずみ線を 任意に評価することが可能である。したがって， $\Delta t$ 秒後にせん断応力 $\tau$ が作用するとして，この時 のひずみが仮に $\gamma$ 。となるに必要な繰返し回数 $N_{e q}$ は,

$$
N_{e q}=\frac{C_{1}+C_{2}\left|\gamma_{o}\right| /(1+v)}{\left|\tau / \sigma{ }^{\prime}\right|-R_{\min }}
$$

と表せる，せん断応力が増加する過程においてゼロ クロス点を超えれば，どの時点で折り返したとして も，前回の折り返し点を基準にすれば，半サイクル のせん断応力波形が作用したものと見なせる. した がって， $\Delta t$ 秒後に引き続きせん断応力 $\tau$ が作用す る時のひずみ $\gamma$ は， $N=N_{e q}+0.5$ として式(1)に 代入すれば,

$$
\begin{aligned}
|\gamma|= & \left\{\left(\left|\tau / \sigma^{\prime}{ }_{d}\right|-R_{\min }\right)\left(N_{e q}+0.5\right)-C_{1}\right\} \\
& (1+v) / C_{2}
\end{aligned}
$$

と与えられる.

さらに，先に定義された有効応力比〜ひずみ関係 に，上式から与えられるひずみを代入すれば，

$\left(=\tau_{0}+\Delta \tau\right)$ 絮作用する時の有効応力を定める ことが可能となる．したがって，各時間ステップ毎 に上記の評価を行うことにより，有効応力が回復し ていく過程の応力経路が定義される.

\section{b）有効応力の減少領域}

サイクリックモビリティ時の有効応力経路は，有 効応力の回復と減少を繰り返す.この時せん断応力 の大きさにもよるが， $\tau=0$ のゼロクロス点におい て直ちに $\sigma^{\prime}=0$ とはならずに, 徐々に原点に近付 いて行く挙動を示す．これに伴い，図-15のハッチ に示されるような, 有効応力減少過程の経路と位相 を転じる点の有効応力比とで囲まれるループの面積 


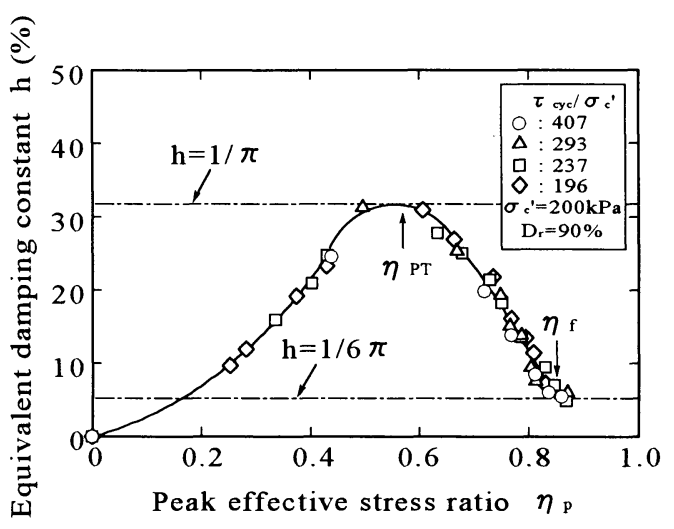

図-17 ピーク有効応力比と等価減衰定数の関係 （豊浦砂 $D_{r}=90 \%$ )

は，繰返しとともに減少していく．

図-17は，豊浦砂 $D_{r}=90 \%$ の応力サイクルピーク 時の有効応力比 $\eta_{p}$ と等価減衰定数 $h$ の関係を示し たものである. 図中には，併せて静的非排水試験結 果から得られた変相時の有効応力比 $\eta_{P T}$ と破壊時の 有効応力比 $\eta$ ，についても示した. 初期の段階でh は増加傾向にあるが， $\eta_{P T}$ を境としてそれ以降は， 減少に転じることが分かる．したがって，サイクリ ックモビリティ時には, 有効応力経路上のループの 面積と減衰定数とが共に減少傾向にあるようである.

そこで，有効応力減少領域の応力経路を定義する にあたり，図-15のハッチで表される有効応力経路 上のループの面積 $\Delta S$ と減衰定数 $h$ とが,

$$
\Delta S=\pi h \tau_{0}^{2} /\left|\eta_{0}\right|
$$

と表される等価な関係があると考えた。ここで， て。, $\eta_{0}$ はそれぞれ図に示される折り返し点でのせ ん断応力, 有効応力比である.

次に, 有効応力の減少過程における応力経路 $(\mathrm{d}$ $\rightarrow \mathrm{e} \rightarrow \mathrm{f}$ ） は次式で与えた.

$$
\sigma^{\prime}=\sqrt{(\tau-c) / a}
$$

ここで，上式を基にして定められる $\Delta \mathrm{S}$ を, 式(15) に代入すれば, 変数 $a, c$ は, それぞれ次のように 与えることができる.

$$
\begin{gathered}
a=\frac{3+\sqrt{3(2 \pi h+1)}}{6 \tau_{0}(1-\pi h)} \eta_{0}{ }^{2} \\
c=\tau_{o}-a\left(\frac{\tau_{0}}{\eta_{0}}\right)^{2}
\end{gathered}
$$

ここで, 式 (17) の右辺の平方根と分母の部分に着 目すれば，

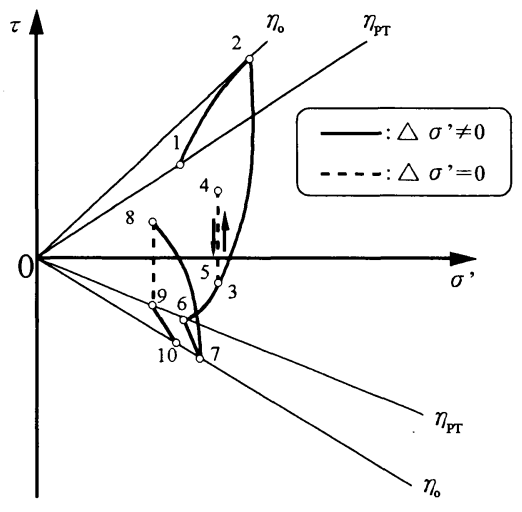

図-18 降伏条件 $\left(\left|\eta_{\max }\right| \geqq|\eta P T|\right)$

$$
\frac{1}{6 \pi}<h<\frac{1}{\pi}
$$

の条件が満足されなければならないことが分かる。 図-17には，この領域についても示しているが，サ イクリックモビリティ時のh はこの範囲内にあるこ とが実験結果からも伺える.したがって， $\Delta S$ には 明確な物理的意味は不明であるが, 現象としては上 記の考え方が妥当であることを示している.

これにより, 式 (16)に定める有効応力の減少過 程における応力経路は, 有効応力が増加傾向から減 少傾向に転じる折り返し点でのせん断応力 $\tau$ 。有 効応力比 $\eta_{0}$, そして減衰定数 $h$ が与えられれば計 算される. ここで, $\tau$ 。 $\eta_{0}$ については, 応力経路 の計算過程において必然的に求められるが， $h$ につ いては式 (19) の条件を満足する次式を与えた.

$$
h=\frac{1}{6 \pi}+\frac{h_{\max }-1}{6 \pi}\left(\frac{\eta_{o}-\eta_{f}}{\eta_{P T}-\eta_{f}}\right)^{2}
$$

ここで， $h_{\max }$ は最大減衰定数である.上式によれば, $h$ は $\eta$ 。の増加に伴い限りなく $1 / 6 \pi$ に漸近する形 で低下していく.

図-18には，サイクリックモビリティ時の降伏条 件を示した。図-19に豊浦砂 $D_{r}=90 \%$ に対して実施 した不規則載荷による繰返し三軸試験結果と, 提案 モデルによる計算結果とを比較した。ここで，不規 則波形はタフト NS 波 (1952) を用い，この加速度記 録と相似な波形を荷重として載荷している．計算結 果は実験結果と良好な対応関係にあるが, 特に変相 線に達した後の過程において, 破壊線に漸近する形 で応力回復を繰返しながら徐々に有効応力が減少し ていく様子や, 応力回復に伴う応力〜ひずみ曲線の 形状等, 飽和砂のサイクリックモビリティ特有の挙 


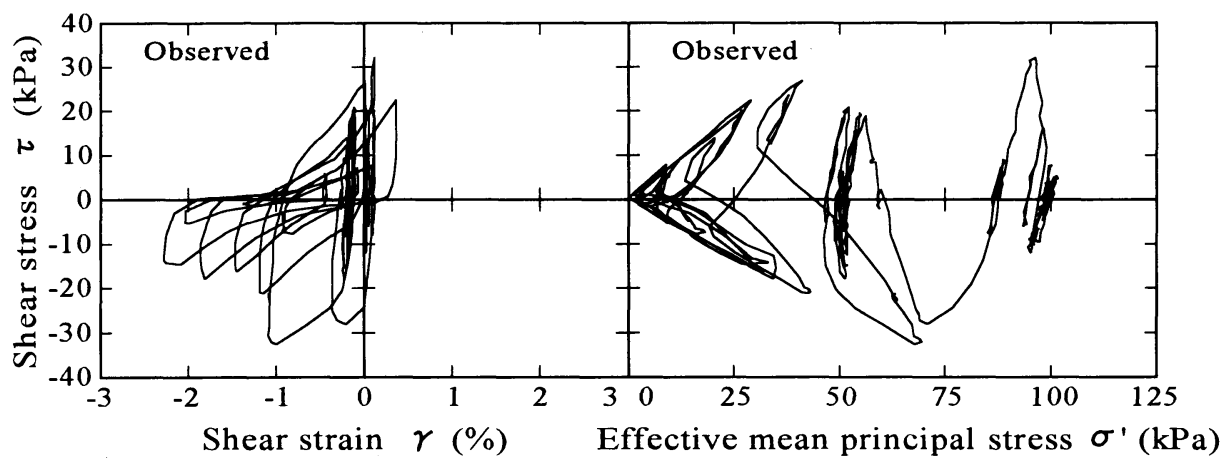

(a) 繰返し三軸試験結果（豊浦砂 $\left.D_{r}=90 \%\right)$

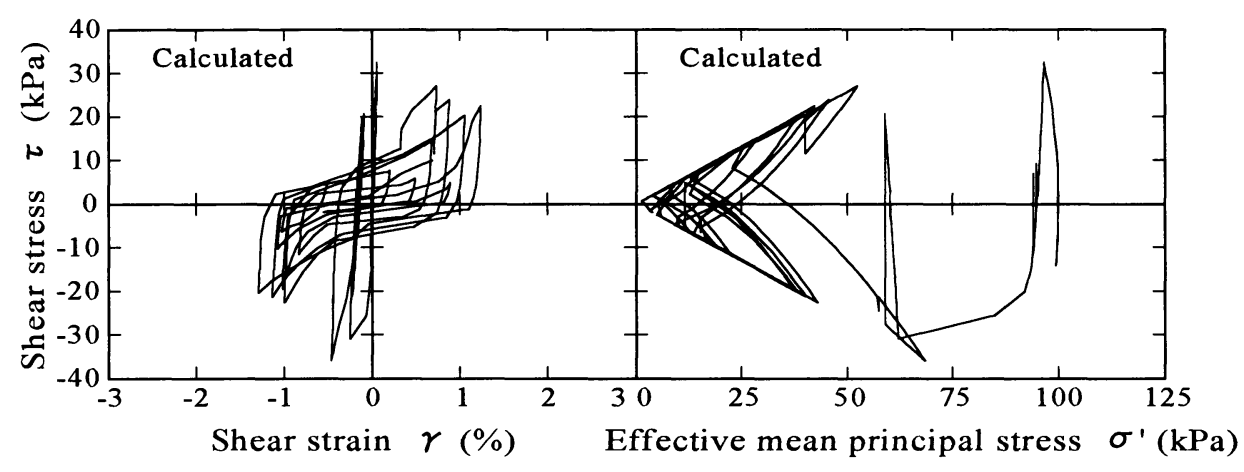

(b) 提案モデルによる計算結果

図-19 不規則載荷による試験結果と計算結果の比較

動をうまく表現していることが分かる．また，この 他の実験結果に対する検討から，計算結果の精度が 過剩間隙水圧, 変形量とも液状化強度線の回㷌の精 度に直接依存することを確認している.

\section{（3）提案モデルの粘性土への適用}

提案モデルは飽和砂の液状化を前提としているが, 試験から与えられる強度曲線を直接取り入れている ので，粘性土に対してもこれを用いる限りにおいて は, 飽和砂と同様な方法で破壊過程の変形を評価す ることが可能と考える. 後で解析結果を示すポート アイランドでは G.L-19〜 -27m にかけて沖積粘土層 があるが，文献 18)によれば，ほぼ正規圧密の状態 にあり，塑性指数は概ね 60 以上と日本の海成粘土 としては比較的高塑性であることが示されている. そこで，ここでは等方正規圧密状態下の高塑性粘土 の繰返し挙動に対するモデルの適用を試みる，ただ し, 粘性土については顕著な載荷速度依存性の挙動 を示すことが知られているが，これについては今後 の課題とし，ここでは時間依存性がないものと仮定 する.

図-20は，ポートアイランドの沖積粘土とほぼ同
等の塑性指数を有する五日市粘土 $\left(I_{P}=72.8\right)$ の 繰返し三軸試験結果 ${ }^{19)}$ を示したものである．有効 応力比〜ひずみ関係については砂質土と同様の評価 が可能なことが分かる．一方，応力経路は砂の液状 化のように間隙水圧が初期拘束圧に等しいまでは上 昇することはなく，限界状態線 CSL に漸近する形 で定常なループを描く．したがって，破壊過程の応 力経路をどのように提案モデルで表現するかが問題 となるが，これについては次のように考えた.

まず，変相線であるが，当然のことながらこの場 合変相線は存在しない。しかしながら，破壊過程の 応力〜ひずみ関係は緩やかながら硬化型のループを 描いている. そこで，変相状態を変形の発達が変化 する点と考え, 有効応力比〜ひずみの双曲線関係に おける変曲点の応力比がこれに相当するものとして 代用する.

次に, 破壊過程における間隙水圧の発生量である が, これについては, 式 (16)〜 (18)により破壊過 程の減衰定数に関係付けられている. 図-21は，応 カサイクルピーク時の有効応力比 $\eta_{p}$ と等価减衰定 数h の関係を示したものである.この場合, 図-17 に示した豊浦砂の試験結果とは異なり, $h$ は $\eta_{p}$ の 


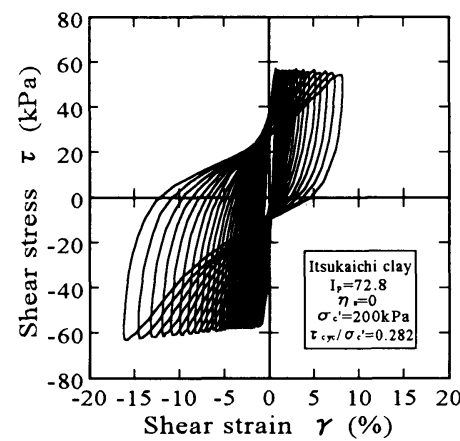

（a ）せん断応力・せん断ひずみ関係

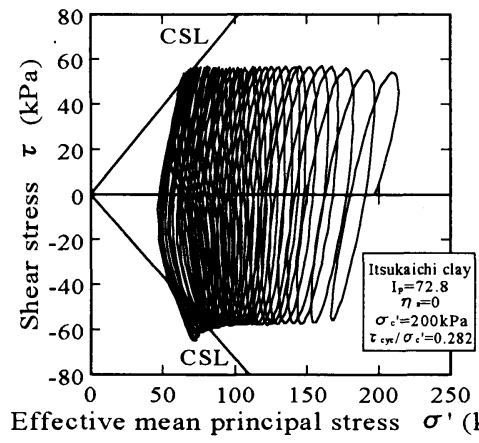

(b) 有効応力経路

図-20 五日市粘土の繰返し三軸試験結果

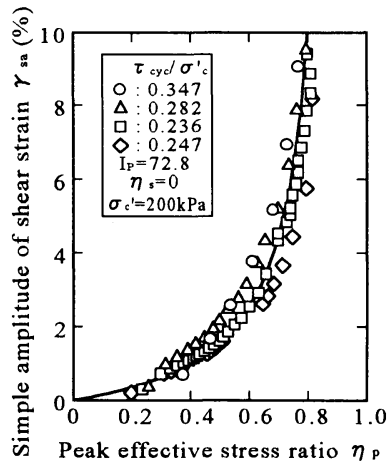

(c) ピーク有効応力比. 片振幅ひずみ関係

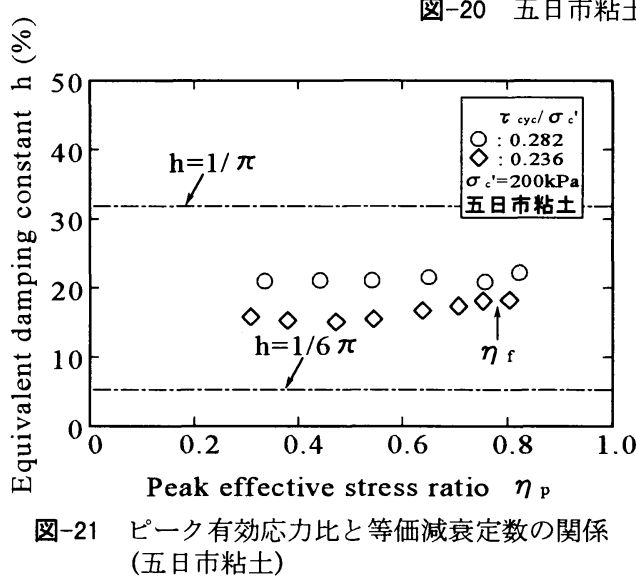

増加に対してほとんど変化しないか, 微増する程度 の傾向にある. したがって, 破壊過程における粘土 のh には式 (20)に代わるものとして, 次式が与え られる。

$$
h=h_{\max }
$$

図-22に繰返し三軸試験結果とモデルによる計算 結果の比較を示した. 図の実験結果は, 繰返し回数 4 回目で静的試験から得られた限界状態線に達して, 以降の間隙水圧は定常な状態にあるのだが，このよ うな粘性土特有の挙動や破壊過程の大変形について, 計算結果は試験結果を良好に表現しており，提案モ デルが粘性土に対しても適用可能であることが明ら かである.

\section{5. ポートアイランド鉛直アレー観測記録の シミュレーション}

\section{(1) 解析概要}

\section{a ）地盤モデル}

ポートアイランドの鉛直アレー観測では, GL-83m の記録に方向誤差があること ${ }^{3)}$. 20)，

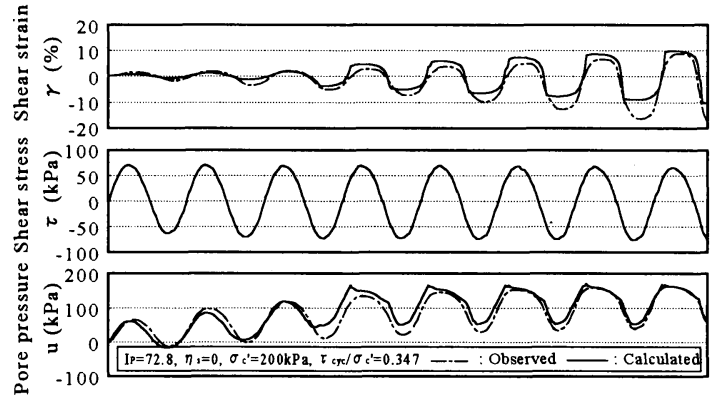

図-22 粘土に対する試験結果と計算結果の比較

GL-32m 以浅の沖積砂層と埋土層での液状化の可能 性が指摘されていることから ${ }^{21)}$, 本解析では GL-32m 以浅の地盤を解析の対象とした.

表-1に解析用地盤モデルを示す. 地下水位は文献 21）の報告より GL- $2.4 \mathrm{~m}$ に設定した. 初期剛性 $G_{\text {max }}$ は，PS 検層結果 ${ }^{22)}$ を基に拘束圧依存性を考慮す る形で設定し, 砂質土の内部摩擦角は, 大崎の式か $ら N$ 值より $\phi=\sqrt{20 N}+15$ として設定した. 粘性 土の $\phi$ については, 図-20の試験結果から設定した.

提案したモデルにおいて最も重要なパラメータは 強度曲線に関する定数 $\left(C_{1}, C_{2}, R_{\min }\right)$ であるが, 埋土層と沖積粘土層については, 地震後に採取され た不擤乱試料に対して繰返し三軸試験が行われてい $3^{22)}$. 図-23に各層の強度曲線を示す。図 ( a ) , （b）のプロットがそれぞれ埋土層, 沖積粘土層の

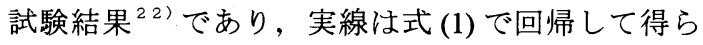
れたものである.また, 図 (c ）に示した GL-27m 〜 -32m の沖積砂層のプロットは, 原子力発電所耐 震設計技術指針 ${ }^{23)}$ に示されている液状化判定法 ${ }^{24)}$ から $D A=2 \%, 5 \%$ の強度を $N$ 值から算定して求 めた推定値である. 図-24に回帰した強度曲線から 
表-1 解析地盤モデル (ポートアイランド)

\begin{tabular}{|c|c|c|c|c|c|}
\hline $\begin{array}{l}\text { 深度 } \\
\mathrm{GL} \\
(\mathrm{m})\end{array}$ & 土 質 & $\mid \begin{array}{c}\text { 地震㖕 } \\
\text { 位要 }\end{array}$ & $\begin{array}{l}\text { 密度 } \\
\mathrm{t} / \mathrm{m}^{3}\end{array}$ & $\begin{array}{l}\text { 初期剛性 } \\
\mathrm{G}_{\max }(\mathrm{MPa})\end{array}$ & 液状化パラメータ等 \\
\hline 0 & $\nabla^{\text {埋土層 }}$ & & 1.9 & $300 \sigma_{\mathrm{m} 0}^{\prime} 0.5$ & $\begin{aligned} \nu & =0.35 \quad \phi^{\prime}=25.8^{\circ} \\
\mathrm{K}_{0} & =0.5\end{aligned}$ \\
\hline & $\overline{\bar{F}}-2.4 \mathrm{~m}$ & $\begin{array}{l}\text { GL } \\
-16 \mathrm{~m}\end{array}$ & 1.9 & $300 \sigma^{\prime}{ }_{\mathrm{m} 0}^{0.5}$ & $\begin{array}{l}\nu=0.35 \quad \phi^{\prime}=25.8^{\circ} \\
\mathrm{K}_{0}=0.5 \quad \mathrm{~h}_{\max }=0.20 \\
\mathrm{R}_{\min }=0.15 \quad \mathrm{a}=40 \\
\mathrm{C}_{1}=0.309 \quad \mathrm{C}_{2}=0.146 \\
\mathrm{~B} / \sigma^{\prime}{ }^{\prime} 0=0.841\end{array}$ \\
\hline 19 & & & & & \\
\hline 27 & $\begin{array}{l}\text { 沖皘 } \\
\text { 粘土居 }\end{array}$ & & 1.6 & $138 \sigma_{\mathrm{m} 0}^{\prime} 0.5$ & $\begin{array}{l}\nu=0.40 \quad \phi^{\prime}=38.2^{\circ} \\
\mathrm{K}_{0}=0.5 \quad \mathrm{~h}_{\max }=0.20 \\
\mathrm{R}_{\min }=0.28 \quad \mathrm{a}=40 \\
\mathrm{C}_{1}=0.018 \quad \mathrm{C}_{2}=0.244 \\
\mathrm{~B}^{\prime} \sigma^{\prime}{ }_{\mathrm{m} 0}=0.709\end{array}$ \\
\hline 32 & 沖積砂層 & & 1.9 & $277 \sigma_{\mathrm{m} 0}{ }^{0.5}$ & $\begin{array}{l}\nu=0.35 \quad \phi^{\prime}=31.4 \\
\mathrm{~K}_{0}=0.5 \quad \mathrm{~h}_{\max }=0.30 \\
\mathrm{R}_{\min }=0.22 \quad \mathrm{a}=40 \\
\mathrm{C}_{1}=0.3 \quad \mathrm{C}_{2}=0.2 \\
\mathrm{~B} / \sigma^{\prime}{ }_{\mathrm{m} 0}=1.020\end{array}$ \\
\hline
\end{tabular}

与えられた定数 $\alpha$ と片振幅軸ひずみ $\varepsilon_{S A}$ の関係を 示した.ここで，図中の実線はいずれも式 (2) で回 帰したものである．これらの回帰により強度曲線に 関するすべての定数が設定された.

\section{b ) 解析方法}

解析は，水平成層地盤を仮定した一次元問題とし， 提案モデルを用いた有効応力解析と比較のため非線 形全応力解析の 2 種類の方法で行った. 地盤は直列 のせん断多質点系でモデル化し，逐次積分法による 時刻歷解析によって各質点の応答を評価している. また，有効応力解析は非排水条件で行っており，地 盤の透水性は考慮していない, 全応力解析は, 提案 モデルにおいて過剩間隙水圧の発生がないものとし て計算を行っているので, Hardin- Drnevichi モデル による非線形解析に相当する．解析方向は観測記録 波形振幅の大きい NS 方向とし， GL-32m での観測 波を入力動とした.

\section{(2) 解析結果}

図-25に地表面と GL-16m における加速度の観測 波形と解析波形の比較を有効応力, 全応力解析につ いて示した. 有効応力解析結果の図中に示した矢印 は初めて変相線に達したポイントを表している。ま た，図-26にはこれらに対応する応答スペクトルを 示した.

まず，地表面の加速度波形について見れば，有効 応力解析結果は, 液状化に伴う長周期化や応答の低 下を良好に評価して観測波形に適合している.これ に対し，全応力解析結果は位相が大きく進行する形 で観測波形と大きく異なる傾向を示している．また，

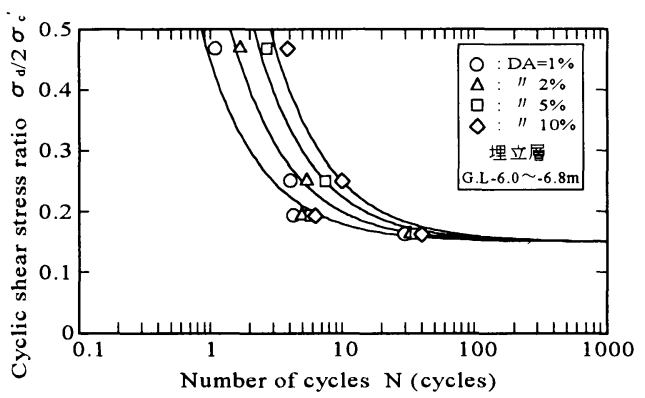

(a) 埋土層 (GL-6.0 -6.8m)

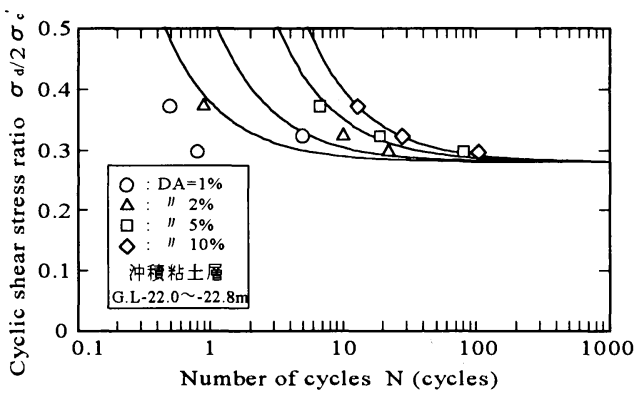

（b）沖積粘土層（GL-22.0～-22.8m）

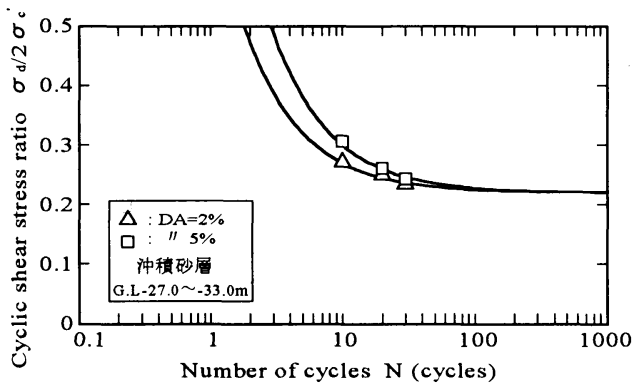

（c）沖積砂層（GL-27〜-32m)

図-23 各層の強度曲線

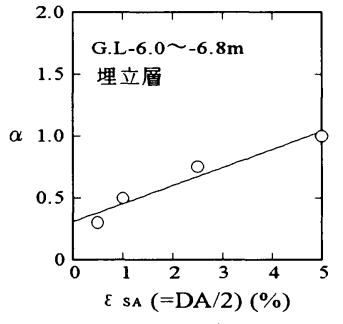

(a) 埋土層

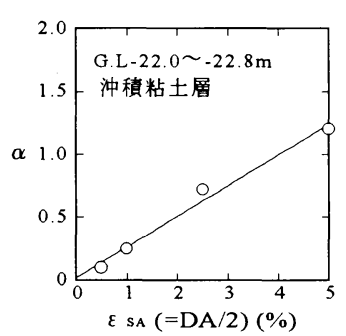

（b）沖積粘土層

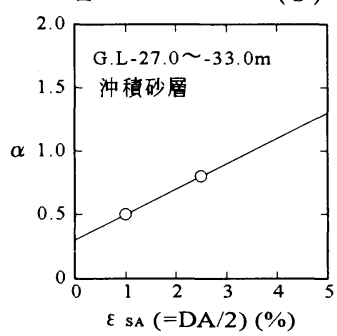

(c) 沖積砂層

図-24 定数 $\alpha$ と片振幅軸ひずみの関係 

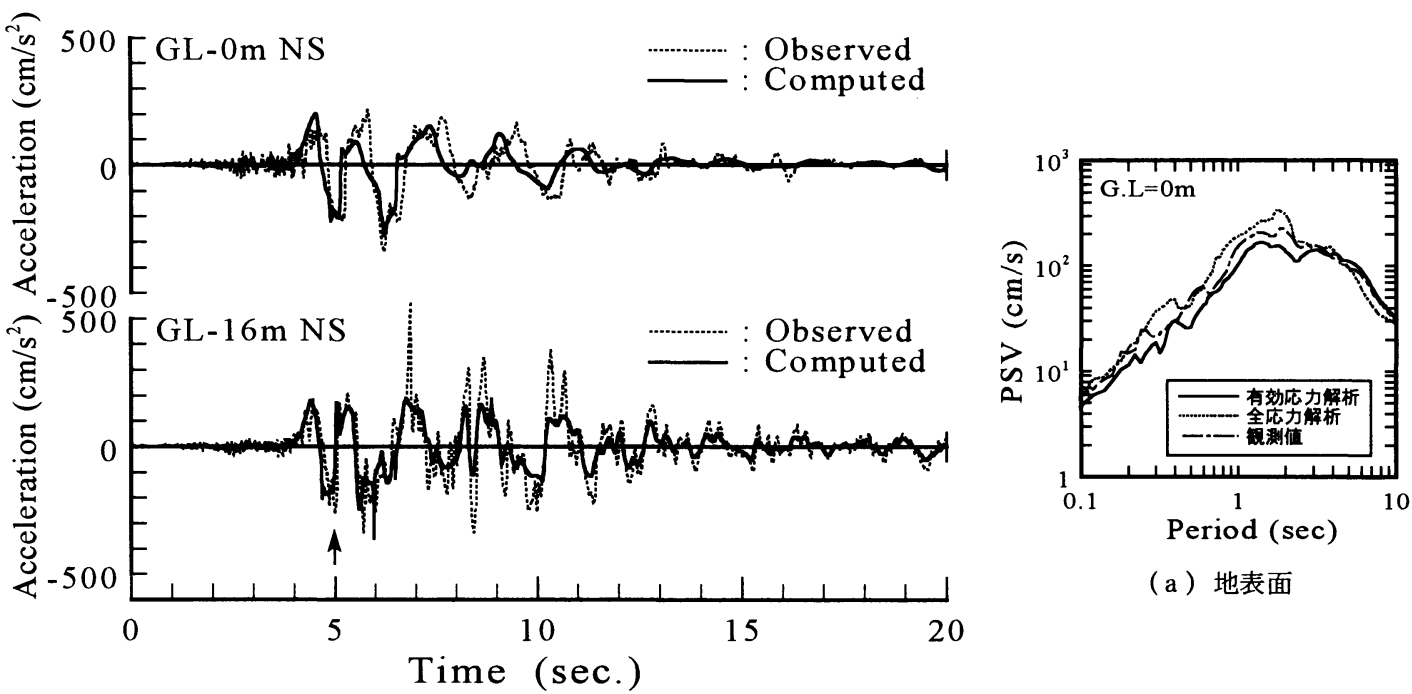

（a ）地表面

(a) 有効応力解析結果
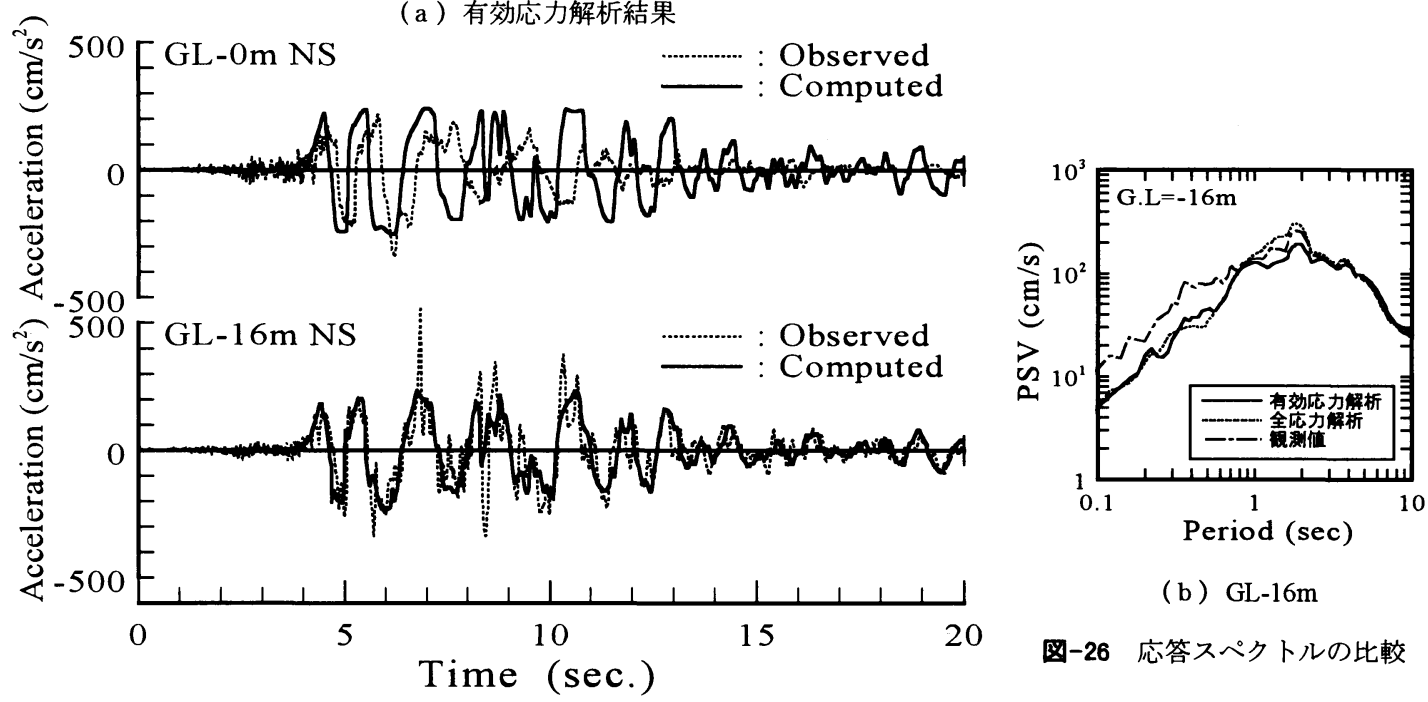

(b) GL-16m

図-26応答スペクトルの比較

(b) 全応力解析結果

図-25 加速度時刻歴の比較

応答スペクトルからも有効応力解析結果が観測値の 応答をよく表しているのに対し, 全応力解析は 2 秒 以下の短周期の応答を大きく， 5 秒以上の長周期の 応答を小さく評価しており，短周期側にシフトした 傾向にある．これは，これまでに言われているよう に全応力解析では液状化のような大変形を評価しき れないことを表している.

次に, GL-16m の加速度波形について見れば, 全 応力解析結果は観測波形よりもやや長周期側になる 形で徐々に位相がずれて行くのが分かる。これに対 して, 有効応力解析結果と観測波形の位相はよく一 致している. また，有効応力解析の加速度波形の方 がピーク付近において鋭く立ち上がる形状を示して
おり，観測値により近い結果となっている。したが って, 観測地点においても有効応力解析結果とほぼ 同時点で変相状態に至り, それ以降は, 図-27の有 効応力解析結果に示すようなサイクリックモビリテ イ特有の現象が生じたことが推測できる．ただし， 応答スペクトルにはここで述べたような解析方法の 違いによる大きな違いは認められず，いずれの解析 結果も短周期側の応答を過小評価していることが分 かる.これは両解析の加速度波形において, 図の時 間で 7 秒〜 11 秒にかけての観測值のピークを過小 評価していることが主な要因と考えられるが，この 理由として次のことが考えられる.

まず，全応力解析の場合，ひずみレベルが大きい 


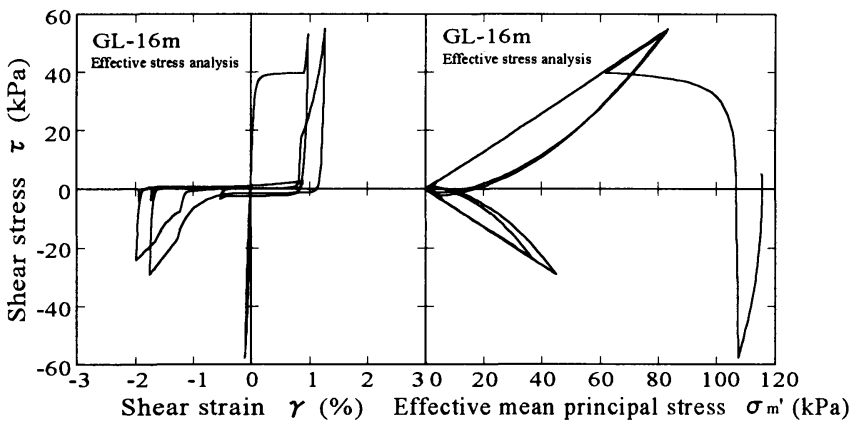

(a) 有効応力解析結果

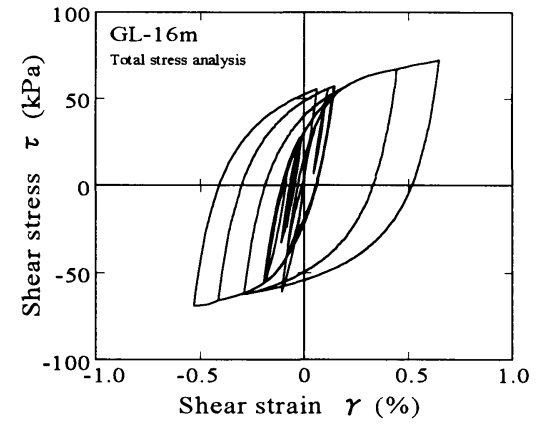

(b) 全応力解析結果

図-27 各解析結果のせん断応力・せん断ひずみ関係と有効応力経路（GL-16m）

ところにおいて履歴減衰が著しく増加する傾向にあ るために，破壊過程においてその答を小さく評価 してしまう. 有効応力解析の場合は, GL-16m 付近 の 值がこれ以外の埋土層よりも大きいことから， 図-23（a）に示した液状化強度線より，もっと硬 化型の強度線であった可能性が高く, サイクリック モビリティ時において解析結果に示した以上の激し い剛性の変化を生じたものと考えられる.

図-28には，各解析における地盤の最大応答値の 分布を示した. 最大加速度について見ると, 有効応 力解析と全応力解析では, 全体的に全応力解析結果 の方がやや小さめの值となっている. 加速度分布は, 両解析結果とも沖積粘土層において低下する傾向を 示しいるが, 全応力解析の応答が著しく低下するの に対して, 有効応力解析結果のそれはさほど低下し ない興味深い結果となった. 過剩間隙水圧比の分布 と.図-29の時刻歴から埋土層が最初の大きな摇れに より液状化に至ったことが分かるが，粘土層におい ても引き続く大きな摇れによって, 静的試験から得 られた限界状態線に達し, 以降定常な間隙水圧挙動 を示している. したがって, 粘土層において強い非 線形が生じたことは間違いないものと考えられるが, ここで示した全応力解析法では粘土の破壊過程にお ける応答を過小評価してしまう恐れがあることを解 析結果は示している. 粘土層の応答は上層の埋土層 の応答に大きく影響しており，有効応力解析におい て粘性土の破壊過程の挙動をモデル化することの重 要性を示唆している.

\section{6. 結 論}

本研究は, 地震時の地盤の破壊過程における非線 形性についても適切な評価が可能な実用性の高い有 効応力モデルの提案を試みたものである. 提案手法 の特徵は, 繰返し試験結果として最も一般的な繰返

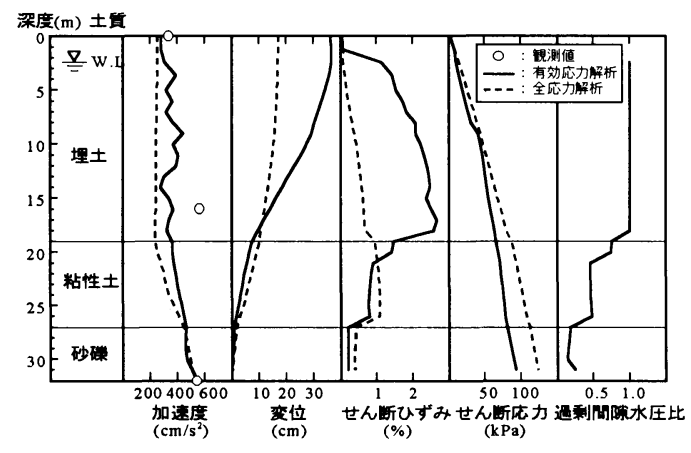

图-28 最大応答值の比較

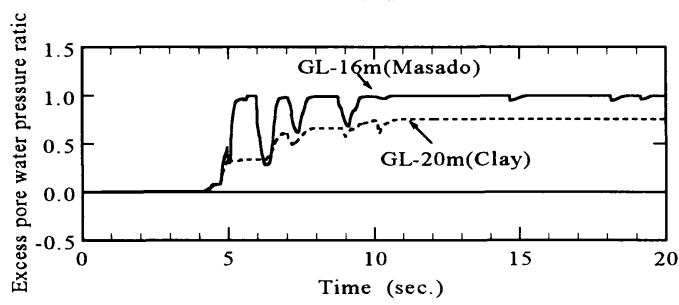

図-29 過剩間隙水圧比の時刻歴

し強度・繰返し回数関係を直接用いたこと, 実験結 果を踏まえてモデルを構築することにより，解析パ ラメータの設定を容易にしかつその根拠を明確にし たことである.

提案モデルによる繰返し三軸試験のシミュレーシ ヨンの結果, 飽和砂のサイクリックモビリティのみ ならず粘性土の破壊過程についても適切な評価が可 能であることが明らかとなった。 また，提案モデル を用いた有効応力解析によるポートアイランドの鉛 直アレー観測記録のシミュレーションの結果, 強度 線を適切に与えることによって, 強い非線形性を伴 う強震動時の地盤応答についても精度の高い解析が 可能であり，本提案手法の妥当性が明らかになった. また, 同観測地点の埋土層ではサイクリックモビリ ティに伴う激しい剛性の変化が生じていたことが明 
らかであり, 粘土層の応答性状が上層の埋土層の応 答に大きく影響している等, 地盤の破壊過程におけ る非線形性を適切に評価する有効応力解析法の重要 性が明らかとなった.

なおここで用いた記録波形は神戸市によって観 測されたもので, 関西地震観測研究協議会を通じて 提供していただいた.

\section{参考文献}

1) 吉田望：1995 年兵庫県南部地震におけるポートア イランドの地震応答解析, 土と基礎, Vol. 43, No. 10, pp. 49-54, 1995.

2) 川瀨博, 佐藤智美, 福武毅芳, 入倉孝次郎：兵庫 県南部地震による神戸市ポートアイランドでのボ アホール観測記録とそのシミュレーション, 日本 建築学会構造系論文集, 第 475 号, pp. 83-92, 1995.

3) Sugito, M., Sekiguchi, K., Yashima, A., Oka, F., Taguchi,Y. and Kato, Y. : Correction of Orientation Error of Borehole Strong Motion Array Records Obtained during the South Hyogo Earthquake of JAN. 17, 1995, Proc. of JSCE, No. 531/I-34, pp. 51-63, 1996.

4) 森伸一郎, 三輪滋, Guan Baoqi : 液状化した地盤 の地震時挙動に関する検討, 第 22 回地震工学研究 発表会, 土木学会, pp. 51-54, 1993.

5) 井合進, 松永康男, 森田年一, 桜井博孝: 釧路港 湾での強震動の特徵, 第 21 回地盤振動シンポジウ 么, 日本建築学会, pp.33-42, 1993.

6) Castro, G. and Poulos, S. J. :Factors Affecting Liquefaction and Cyclic Mobility, Proc. of ASCE, Vol. 103, No. GT6, pp. 501-516, 1977.

7) Vaid, Y. P. and Chern, J. C. : Cyclic and Monotonic Undrained Response of Saturated Sands, Advances in the Art of Testing Soils under Cyclic Conditions, ASCE Convention, Detroit, pp. 120-147, 1985.

8) 東拓生, 大塚久哲, 二宮嘉朗：砂質土の相対密度 を考虑した液状化強度曲線の定式化, 土木学会第 49 回年次学術講演会概要集, III, pp. 528-529, 1994.

9) 柴田徹, Djoko S. Soelarno：繰返し載荷を受ける砂 質土の応力・ひずみ特性, 土木学会論文報告集, 第 239 号, pp. 57-65, 1975.

10) Hyodo, M., Murata, H., Yasufuku, N. and Fujii, T. : Undrained Cyclic Shear Strength and Residual Shear
Strain of Saturated Sand by Cyclic Triaxial Tests, Soils and Foundations, Vol. 31, No. 3, pp. 60-76, 1991.

11) 原勝重, 龍岡文夫, 佐藤剛司: 砂の非排水繰返しね じりせん断における詳細な応力〜ひずみ関係，第 19 回土質工学研究発表会, pp. 577-580, 1984.

12) 三原正哉, 西邦夫 : 繰返し載荷を受ける砂の非排水 時・応力〜ひずみ曲線のモデル化, 第 20 回土質工 学研究発表会, pp. 617-620, 1985.

13) Hardin, B. O. and Drnevich, V. P. : Shear modulus and damping in soils : Design equations and curves, Proc. of ASCE, Vol. 98, No. SM7, pp. 667-692, 1972.

14) 国生剛治, 桜井彰雄 : Modified Hardin-Drnevich モ デルについて, 土木学会第 33 回年次学術講演会概 要集, III , pp. 116-117, 1978.

15) Ishihara, K. and Touhata, I. : One-Dimensional Soil Response Analysis during Earthquakes Based on Effective Stress Method, Journal of the Faculty of Engineering, University of Tokyo(B), Vol. 35, No. 4, pp. $655-700,1980$

16) Martin, G.R., Finn, W. D . L . and Seed, H. B. : Foundamentals of Liquefaction under Cyclic Loading, Proc. of ASCE, Vol. 101, No. GT5, pp. 423-438, 1975.

17) 石井雄輔, 吉見吉昭 : 不規則繰返しせん断による砂 のダイレイタンシー特性及び液状化抵抗, 第 14 回 土質工学研究発表会, pp. 577-580, 1979.

18）地盤工学会関西支部: 海底地盤一大阪湾を例として 一, 1995 .

19）兵動正幸, 杉山太宏, 山本陽一, 河田頼治 : 繰返し せん断を受ける正規圧密および過圧密粘土の間隙 水圧とひずみの評価, 土木学会論文集, No.487/ III -26, pp. 79-88, 1994.

20)吉田郁政, 栗田哲史 : 兵庫県南部地震の観測記録を 用いたポートアイランド表層地盤の動特性の逆解 析, 土と基礎, Vol. 43, No. 9, pp. 44-48, 1995.

21）地盤工学会阪神大震災調查委員会 : 阪神 - 淡路大震 災調查報告書（解説編），1996.

22）神戸市開発局 : 兵庫県南部地震による埋立地地盤変 状調查（ポートアイランド，六甲アイランド）報 告書, 1995.

23）日本電気協会：原子力発電所耐震設計技術指針, 1987.

24）国生剛治，吉田保夫，長崎清 : 密な砂地盤の $\mathrm{N}$ 值 による液状化判定法, 第 19 回土質工学研究発表会, pp. 559-562, 1984.

(1996. 8. 23受付)

\section{EFFECTIVE STRESS MODEL OF SAND AND CLAY BASED ON CYCLIC SHEAR STRENGTH AND ITS APPLICATION TO LIQUEFACTION ANALYSIS}

\section{Youichi YAMAMOTO, Masayuki HYODO, Ichiro KUROSHIMA and Masaharu TANIGAKI}

An effective stress model which can evaluate the undrained cyclic shear behaviour of sands and clays is proposed in this paper. The model is constituted of effective stress ratio and strain model and an effective stress path model which is developed by using the cyclic strength curves of soils. Cyclic mobility behaviour can be reasonablly simulated in the model. A response analysis was performed on the site where liquefaction was happend and seismic motion was recorded by borehole array during Great Hanshin Earthquake by applying the proposed model. Accuracy of the model was verified by comparing the analytical result with observed one. 